\title{
Informal Settlements in Jordan
}

\section{Upgrading Approaches Adopted and Lessons Learned}

\section{Jamal I. Al Daly}

Sociologist

Housing and Urban Development Corporation, Jordan

\section{Introduction}

During the last four decades informal settlement (upgrading sites) in Jordan were grown in the core and around the urban centres and became one of the crucial urban problems, which created a cute housing problems and severe pressure on infrastructure services and community facilities. The number of these settlements exceeded 40 settlements all over the country, inhabited with more than 100.000 people, they have deteriorated environment and were being assigned as the poorest communities in the urban areas.

In 1979 the Government of Jordan start to bee more concerned about the problems of the people living in these settlements and decided to implement a pilot project involves a new approach. In mid 1980 the Jordan Government established the Urban Development Department (UDD) a new organisation amid to improve the physical environment of these settlements and to provide low -income housing. Since then, the Government adop ted several strategies.

This paper intended to compare and analyse the different strategies were adopted by the government to handle this issue, and to assess their performance. Moreover the paper will highlight the role of different actors in the upgrading process and will discuss the informal settlement profile; growth, characteristics, population profile and land tenure patterns.

\section{General Background}

\subsection{Country Background}

Jordan is country of 4.4 million population. Situated in the middle east, in the western parts of Asia; north west of Saudi Arabian with $89000-\mathrm{km}^{2}$ area. The terrain mostly desert plateau in the east, highland area in the west;
Great Rift Valley separates east and West Banks of Jordan River. The climate mostly arid in the dessert rainy season in west (Nov. to Apr) average temperature in summer $25^{\circ} \mathrm{C}$ while average in winter is $7^{\circ} \mathrm{C}$.

Jordan has limited natural resources like Phosphate, Potash and Shale Oil and has limited natural fresh water resources as well. Age structure; 0-14 years 43\%, 15-64 years $54 \%$ and 65 years and over $3 \%$. Population growth rate is $2.54 \%$ (1998)

\subsection{Urban Context}

\section{Urban Growth}

During the last five decades the population of Jordan had increased ten times, part of this rapid growth due to natural increase and immigration from rural areas, while the real reason is political. Jordan experienced three waves of immigration, two due to the Arab Israeli war in 1948 and 1967 and the third one is due to the Gulf war. However, this rapid increase of population created high demands on residential land and infrastructure services in the urban areas. The last national surveys showed that $79 \%$ of Jordan population are living in urban areas.

Jordan, which has limited resources, was required to provide adequate shelter, infrast ructure services and community facilities to address the increasing needs of the population. As the needs were higher than the government capabilities, therefore, thousands of households started to build their shacks and houses illegally on others land as squatters, formulating huge pockets of squatter settlements on the edges of the urban centres.

\section{Land Use and Zoning}

By law the Department of land and Survey is the only government entity which has the mandate of controlling the issue of land tenure. The department always keeps full and updated records about the land ownership in the 
whole country, all actions regarding transferring land ownership must be processed through this department.

According to the regulations related to zoning and land use in urban areas, residential land is zoned into four categories A, B, C and D. These zones vary in minimum plot size, setbacks, length of frontage and building heights to meet the different social groups. The minimum plot sizes are set to be $1000 \mathrm{~m}^{2}, 750 \mathrm{~m}^{2}, 500 \mathrm{~m}^{2}$ and $255 \mathrm{~m}^{2}$ respectively. The results of the National Housing Study in 1986 has shown that their is a vast oversupply of vacant serviced residential land, mostly in zones A and B. While their is under supply of vacant land of zones $C$ and D which are appropriate for middle - income households. And, there are no plots small enough to be affordable to the low-income groups.

\section{Institutional Frame}

Late seventies the government realised that the squatter settlements, which had grown in the last three decades at the edges of the urban centres, in particular the capital Amman as a result of the rapid urban growth, became as a tumour in the core of Amman. They have highly deteriorated environment, poor infrastructure and almost have no community facilities. Therefore, $t$ he Government had established the Urban Development Department (UDD) as a new public organisation with two major tasks, The first; to implement upgrading program in the squatter settlements. The upgrading program involved improving the standards of the physical and social services and to enhance the living conditions of the target groups. The second task, to implement site \& services projects for low-income households in the urban areas. Since then, UDD managed to fulfil its objectives. In April 1992 UDD w as merged with the Housing Corporation ${ }^{1}$ forming Housing and Urban Development Corporation (HUDC). HUDC became fully independent government agency responsible for the housing and urban sectors. The mandates are as follows:

- Main public provider for housing to address the needs of the different groups, in particular, lowincome and middle groups in the Jordan Society

- $\quad$ Reforming the housing sector and develop partnership initiatives with the housing private sector

- Improve the living and housing conditions of the poor $\operatorname{areas}^{2}$ all over the country

\subsection{Informal settlements profile}

\section{Characteristics}

Most of these settlements were built on steeply sloping ground which characterised as the edges of hills 'Jabals' and others were located in valley bottoms which, are subject to flooding during wet weather, Some of the

\footnotetext{
1 The Housing Corporation was established in 1965 as a public organisat ion to provide housing scheme for middle income official employees

2 Referring to squatter settlements and refugee camps
}

slopes are so steep that the ground floors at upper - level house are on the same level and almost touching the roofs of the houses below.

The characteristics of these settlements by households as observed in the baseline surveys in 1981,1982,1986 are summarised as follows:

- $\quad$ The majority of roads and footpaths were narrow and unpaved

- Average plot size approximately $150 \mathrm{~m}^{2}$

- Three-fourth of the houses have rather permanent wall construction with hollow bricks and almost 70 percent of these have concrete roofs, while the remaining have zinc or wood roofs

- 49 percent of the dwelling units are connected to the main water network, while Sanitation facilities are almost non-existent in all the settlements, the vast majority of households depend on pit latrines

- $\quad$ The average persons per room found to be 4.2 , therefor 15 percent of the households have 7 persons per room

- $\quad$ The average household size is 6.8 ,

- 76 percent of the households their income is under the $\left(40^{\text {th }}\right)$ compared to the national income profile.

The average working persons in the household is 1.2 ,while 10 percent of the households have no working persons

- 11 percent of the households are women headed households

- The total fertility rate is 7.4 children

- The proportion of children dying between birth and (age 3 ) is 86 children per thousand births

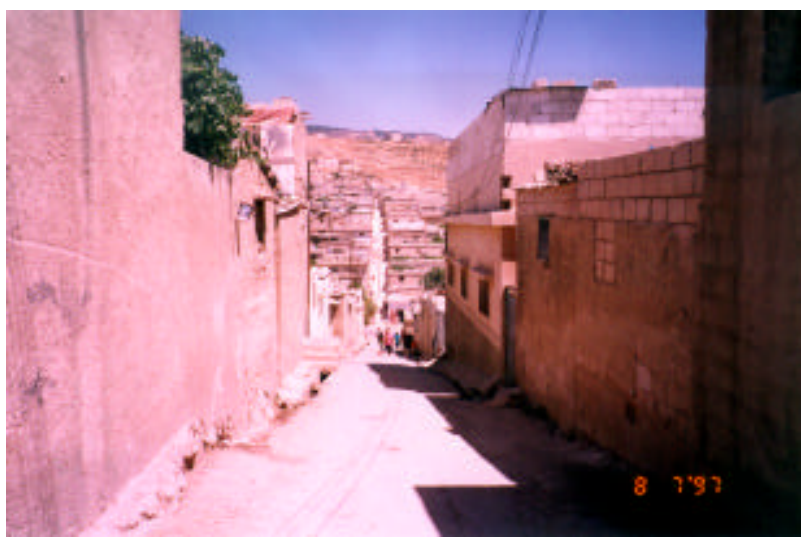

Figure 1 Narrow roads in overcrowded upgrading project

\section{Land Tenure Patterns}

Squatter settlements had grown illegally, either on government land or on private ownership land. Some others have a purchased document known as 'Hejeh'3, not recognised by the Department of Land and Survey (DLS),

3 'Hejeh' is an informal document between the landlord or how claim the land ownership and the buyer, it is not recognised by DLS 
this category had purchased their plot from previous 'owner', it gives only an informal basis for asserting ownership and has no legal standing. The third category, relatively small, is co-owned (Masha') land, they managed to acquire a shared ownership, one legal title for large plot, each household has a certain share with no specific boundaries, they rather, altogether own the plot. The process of parcelling to enable every household get individual land title is quiet complicated and involves legislation procedures

\section{Government Adopted Strategies}

\subsection{Comprehensive Top-Down Approach}

\section{General Aspects}

This approach involved the implementation of comprehensive upgrading for five settlements in Amman and two other settlements in Aqaba City ${ }^{4}$. The program emerged a major intervention, include infrastructure services; water, electricity, sewer, circulation networks and storm water drainage. Furthermore, the program provided the necessary community facilities; schools, clinics, community centres and women vocational training centres.

The program had enabled more than (23000) population squatting in these settlements to secure land title and all infrastructure services (table number 1 ).

Table 1 Basic information on Squatter settlements included in the upgrading program

\begin{tabular}{|l|l|l|l|l|l|}
\hline $\begin{array}{l}\text { Program } \\
\text { Reference } \\
\text { UDP1 }\end{array}$ & $\begin{array}{l}\text { Squatter } \\
\text { Settlement } \\
\text { Wahdat }\end{array}$ & Area $\mathrm{h}$ & Population & $\begin{array}{l}\text { Completion } \\
\text { Date } \\
1984\end{array}$ & location \\
\hline UDP1 & Jofeh & 2.9 & 2500 & 1982 & Amman \\
\hline UDP1 & Rimam & 3.7 & 3500 & 1984 & Amman \\
\hline UDP1 & Nuzha & 2.4 & 3000 & 1988 & Amman \\
\hline UDP2 & $\begin{array}{l}\text { Hia Amir } \\
\text { Hassan }\end{array}$ & 3.0 & 2000 & 1985 & Amman \\
\hline UDP3 & Salahadin & 7.3 & 2000 & 1988 & Aqaba \\
\hline UDP3 & $\begin{array}{l}\text { Shallala } \\
\text { North }\end{array}$ & 11.7 & 5000 & 1991 & Aqaba \\
\hline
\end{tabular}

Source: HUDC quarterly reports

Under this approach, the upgrading program was designed by HUDC and supported by the Word Bank. The target group had been involved indirectly in the upgrading, but they were consulted in the most of stages of the process.

\footnotetext{
${ }^{4}$ Aqaba is a city of 60.000 population, $330 \mathrm{~km}$ south the capital Amman. It is the main harbour of Jordan
}

Therefore, a significant interaction between the beneficiaries and the program elements were observed and stated after the implementation of each project.

\section{Site Planning and Design Concept}

HUDC usually conduct a socio-economic and environmental survey before the design stage of each upgrading project, to collect comprehensive data on land use, construction material, building heights, availability of infrastructure services and households demography. In parallel HUDC undertake a topography survey for each project to identify the housing existing situation includes; dwelling and plot boundaries, open spaces and circulation.

Based on the fieldwork information, planners start develops layout proposal scale 1/500. During the design process, planners stick to low-cost standards and take into consideration the following criteria:

- Roads and footpaths, preferably, follow the existing tracks as possible to avoid demolition and relocation. Therefore, safety measure for traffic purposes must be fulfilled.

- All residential plots must have access either to roads or footpaths; distance between plots and roads should not exceed $50 \mathrm{~m}$.

- Roads usually designed up to the minimum width in accordance to traffic requirements in the area. Wide roads, passing through the upgrading project are not favourable, to avoid heavy and risky traffics.

- Parking areas should be designed to serve residential areas of 100-m diameter.

- Open spaces were designated as green areas as possible

\section{Land Tenure}

The majority of the households in Amman squatter settlements were squatted on private ownership land, while the two settlements in Aqaba were developed on government land. However, HUDC had bought the land from the original owners and reallocated it to occupant households, in most cases each household was allocated the plot, which is being used by it.

To secure land title, each household had to pay back to HUDC the cost of the land through long-term mortgage loans. Therefore, most of the households managed to expand their houses or construct new dwellings.

\section{Relocation}

Demolition always kept to the minimum levels, number of demolition cases were vary from project to another according to the existing squatter settlement conditions and proposal development, its mainly depend on the size of improvement to the circulation networks and on the installation of the infrastructure services as well. Moreover, demolition in some cases was undertaken to reduce overcrowd seeking for adequate and healthy environment. 
Demolition and relocation process, has not been given the appropriate attention in the first batch of upgrading projects which were implemented in Amman, while this process were handled more properly in Aqaba upgrading projects. Demolition cases, fully and partially had been studied carefully and documented in a comprehensive report, includes detailed profile for each demolition parts and socio-ecnomic information on occupants, these information found to be very useful reference for compensation purposes and settling any relevant disputes may appear with any affected household.

Relocates in all upgrading projects were compensated for their properties and they had been given priority to purchase a residential plot or core unit in one of the existing site $\&$ services projects.

\section{Cost Allocation \& Recovery Mechanism}

The concept of upgrading program based on full cost recovery bases. Beneficiaries should have to pay the full cost of on-site infrastructure services and the cost of the land as well, through a long term mortgage loan from the Jordan Housing Bank, while the cost of the community facilities and off-site infrastructure cost elements are considered the government share to the program. The Jordan Housing Bank usually asks the beneficiaries to provide a guarantor, in many cases, the beneficiaries failed to satisfy the bank requirements and some others rejected the idea of getting loan from banks due to religious reasons. Therefore, HUDC had taken the initiative and allowed for this category to pay directly to HUDC with reasonable arrangement, which dose not require any guarantee. Although, the beneficiaries still charged the same interest rate, the bank dose.

In most upgrading projects, some beneficiaries showed reluctant to pay back the cost for different reasons, therefore HUDC had to take further legal actions against defaulters. Exclusive arrangements were made for those who were facing a real difficulties to provide their monthly payments, HUDC use to assess their situation and postponed the due instalments for a period of time, until the household mange to sort out their financial problems.

\section{Community Developm ent \& Gender Issues}

HUDC constructed a community centre in each of the upgrading projects. The objectives of the community centre $^{5}$; to mobilise and organise the local community initiatives, promote income generating activities, literacy campaign, public awareness and encourage women involvement in the community development process. Furthermore, women vocational training centres were built to provide vocational training for women and

5 community centres activities were being designed and supervised by HUDC staff, local community members were trained to run the activities before they stat operating it by themselves promote their economic activities through enabling them to have access to credit program.

Women played essential role in the different stages of the upgrading process, in particular in Amman projects, they had expressed the household's needs and priorities towards infrastructure services and community facilities during the feasibility study and baseline surveys. The majority had been involved directly and helped in the construction activities of their own houses, in most cases, the internal house design was done based on their perspectives.

\section{Actors and Roles}

The upgrading process involved many actors; each had specific role as follows:

\section{HUDC}

HUDC is the sole government agency and the main actor responsibilities include

- $\quad$ Project design for Aqaba upgrading projects

- Finance project implementation

- Project implementation through local contractors

- Co-ordinate with all government services agencies to adapt their standards to fit the concept of lowcost upgrading projects

- Issuing building permits in co-operation with Municipalities

- Supervise the houses construction of beneficiaries

- Cost recovery issues

Joint venture consulting firm

Two consulting firms were involved in the feasibility study and design; one was local and the other was international.

\section{Governmental Agencies}

Include all ministries and institutions concerned with infrastructure and community facilities. They were involved in design criteria and responsible for operation and maintenance. The Department of Land and Survey is a supporting governmental agency which was responsible for checking and finalising the demarcation of each individual plot in all upgrading projects and issuing land titles

\section{Municipalities}

They had the responsibility to revise and approve the layout and building regulations of each upgrading project and approve the building permits as well.

\section{Financing Agencies}

The World Bank was responsible for financing the program components while the Jordan Housing Bank $(\mathrm{JHB})^{6}$ was providing long term Mortgage loans and building material loans for the beneficiaries

\footnotetext{
6 The Jordan Housing Bank was a national para-statal financing agency, and the only bank, which provide long term loans for housing sector. During 1998 the bank became entirely commercial bank
} 


\section{The Target Group}

Beneficiaries were encouraged to identify their needs and priorities during the feasibility stage and baseline surveys. They were responsible for improving their own houses and responsible for paying back the full cost of land and infrastructure services.

\subsection{Comprehensive Partnership Approach}

\section{General Aspects}

This approach involved intensive upgrading for two large squatter settlements in Aqaba City as shown in (table number 2). The upgrading program intervention include; infrastructure services and circulation networks construction. 1350 households were enabled to secure land tenure on serviced plot within a fully services neighbourhood with all needed community facilities.

In the contrary of the previous approach, this program was planned and implemented in full partnership with Local Authorities ${ }^{7}$ and the Target Group beside HUDC. Local Authorities and the Community were involved entirely in the upgrading process includes; site planning, cost allocation $\&$ recovery mechanism and relocation activities.

Table 2 Basic information on Squatter settlements included in the upgrading program

\begin{tabular}{|c|c|c|c|c|c|}
\hline $\begin{array}{l}\text { Program } \\
\text { Reference } \\
\text { UDP3 }\end{array}$ & $\begin{array}{l}\text { Squatter } \\
\text { Settlement } \\
\text { Old town } \\
\text { South }\end{array}$ & 13.1 & $\begin{array}{l}\text { Households } \\
700\end{array}$ & $\begin{array}{l}\text { Completion } \\
\text { Date } \\
1994\end{array}$ & location \\
\hline UDP3 & $\begin{array}{l}\text { Old Town } \\
\text { North }\end{array}$ & 12 & 650 & 1995 & Aqaba \\
\hline
\end{tabular}

Source: Follow-up and Monitoring Survey, Aqaba projects 1996, HUDC

\section{Site Planning and Design Concept}

Socio-economic surveys and topography surveys, still adopted as a fundamental tool to collect the necessary information on the existing situation for both target group and housing profiles, the data used as abase to for site planning and future program assessment. HUDC planners stick to the low cost standards, which were developed through experience in the previous upgrading projects as follows:

- Each residential plot had separate connection for water, sewer and electricity networks

- Efficient circulation networks include 8-10m asphalt roads were provide to serve the majority of the plots

\footnotetext{
${ }^{7}$ Local Authorities in Aqaba include Aqaba Municipality and Aqaba Region Authority (ARA)
}

- $2-4 \mathrm{~m}$ surfaced footpaths were provided to link all households with roads

- Parking areas were provided wherever necessary

- Open spaces allocated as green areas or children playing areas, wherever possible

The target group was entirely involved in the different stages of upgrading. However, final plans including design criteria were reviewed and approved by the local authorities.

\section{Land Tenure}

All households in both upgrading projects were squatting on government ownership land since late forties, some of them have a recognition document from the Department of Land and Survey (DLS) called 'Tawsieya' 8 . Average plot size found to be $100 \mathrm{~m}^{2}$.

HUDC did not acquire the land as used to do in the previous upgrading projects, since the land in the hand of the Local Authorities. Therefore, the Local Authorities had allocated the land to the occupants in co-operation with HUDC at a reasonable price. Although, the 'Tawsieya' holders had got the land at a lower price.

Beneficiaries should take the land title after they complete paying back the land cost to the Local Authorities.

\section{Relocation}

To provide efficient circulation networks to the high dense residential areas, new roads were constructed in both upgrading projects. More than 130 households had been affected by demolition. However, prior to the implementation, adjacent site \& services project was developed by HUDC to relocate these cases. Relevant data on the housing and socio-economic situation were obtained to be used as a reference for compensation purposes.

Demolition cases were given access; either to a subsidised serviced plot or core unit. Poor households were accommodated in core-units at subsidised rent for six moths from the Local Authorities, until they able to build their own houses.

Cost of the new plot have to be paid back to HUDC through mortgage loan from the Jordan Housing Bank, therefore due compensation for each affected household was deducted from the new plot cost.

\section{Cost Allocation \& Recovery Mechanism}

The cost of the upgrading program had been divided among Government, Local Authorities and Beneficiaries. The government share was represented in the provision of the community facilities; in the meantime, Local Authorities were responsible for $50 \%$ of the on-site

8 'Tawsieya' is initial recognition for land allocation given to some households of Aqaba squatter settlements from the DLS during fifties, but the holders of these documents did not accomplished the necessary formal procedures to secure the land title 
infrastructure cost, while beneficiaries had to pay the cost of land and $50 \%$ of the on-site infrastructure services.

However, HUDC as the implementing agency, had financed the implementation of the upgrading components. The Local Authorities were committed to pay HUDC the full cost of the on-site infrastructure services including the beneficiaries share, during a certain period of time.

The majority of beneficiaries, rejected to be engaged in mortgaged loans to any banks, they rather preferred to pay back the cost directly to Local Authorities instead, where no collateral was involved. Although, the latest program assessment indicated a very low repayment rate.

\section{Community Development \& Gender Issues}

HUDC had constructed a community centre to serve the beneficiaries in both upgrading projects, as part of the community facilities package. HUDC specialist staff launched a community development program to encourage community-base initiatives; the local committee was involved during 1992-1994 in series of workshops designed to increase their awareness and promote involvement towards environment improvement and maintains open spaces.

Due to the conservative nature of Aqaba city society, women had not been given the chance to be involved in the early stages of the upgrading process. Therefore, after the implementation of the upgrading, women were promoted to participate in the community centre activities, include vocational training, economic activities and public awareness campaign.

\section{Actors and Roles}

The upgrading program involved many actors, who had specific roles to perform. The actors and their roles as follows:

\section{HUDC}

- Project design in partnership with Local Authorities

- $\quad$ Project implementation through local contractors

- Finance project implementation

- Running the community centres for a certain period of time

- Relocation activities in partnership with LA

Local Authorities (Aqaba Region Authority and Aqaba Municipality)

Local authorities, who were considered as the program owner, they had an effective role in the upgrading include

- Participating in design criteria

- Revising and approving final plans

- Plot allocation and relocation activities

- Financing infrastructure

- Cost recovery

- Issuing building permits

- Maintain green areas and garbage collection

\section{Governmental Agencies}

Include all ministries and institutions concerned with infrastructure and community facilities. They were involved in design criteria and responsible for operation and maintenance. The Department of Land and Survey is a supporting governmental agency which was responsible for checking and finalising the demarcation of each individual plot in all upgrading projects and issuing land titles

\section{Financing Agencies}

The World Bank was responsible for financing the program components while the Jordan Housing Bank was providing long term Mortgage loans and building material loans for the beneficiaries

\section{The Target Group}

Community leaders were involved directly in all stages of upgrading process. They had identified the location of the community facilities. Beneficiaries were responsible for improving their own houses under the supervision of LA and were responsible for paying back the cost of land and infrastructure services according to cost allocation system

\subsection{Anti -Poverty Subsidised Approach}

\section{Background}

Jordan small economic has been subject to many external shocks (phosphate and oil prices), in addition to the return of 300000 Jordanians and disrupted trade pattern due to the gulf war. Economic policy choices made have led to low rate of investment, a small private sector and reliance on government to create employment. The reform program has been slow, at best, to change these factors.

These disruptions have produced large changes in population, production and consumption. Between 1987 and 1991, population including returnees) grew 34\%, unemployment and poverty have become the most pressing social issues all over the country.

At the end of 1996 the Government of Jordan had adopted a national strategy to alleviate poverty among the Jordan society through implementation of targeted and comprehensive national program called Social Productivity Program SPP. The program was designed to enhance the productivity of poor communities, it includes four components; (i) provision of training (ii) develop micro-finance institutions (iii) reform the National Aid Fund ${ }^{9}$ and (iv) improve the physical and social infrastructure of poor communities, this component is being called (Community Infrastructure Program CIP).

The government managed to mobilise the necessary fund, to undertake this program, through different resources, local, regional and international. Some of them are on the form of grants and others as soft loans.

\footnotetext{
9 National Aid Fund (NAF) national governmental organisation provide the necessary financial support for the poorest category in the Jordan society.
} 


\section{General Aspects}

The community infrastructure program CIP-A ${ }^{10}$ was designed in mid of 1997 to be a comprehensive program with the main objectives to improve the living conditions of the poor through the provision of upgrading of essential physical and social infrastructure.

The government, over the years, had made substantial investment through its sectorial ministries to provide essential infrastructure nation-wide. However, there are still a large number of people in urban and rural areas living in sub-standard conditions due to the lack or inadequacy of such services. It is very unlikely these people on their own will ever be able to address such needs. Therefore, the government decided to launch the proposed comprehensive program. The essential services would include; water supply and sanitation (environmentally sound wastewater and solid waste disposal); drainage system to minimise property damage and reduce the risk of loss of human life due to floods; improve safety measures through accessible roads and lighting; provision of schools, health facilities and community centres. Projects are being designed to meet the minimum service quality standards and will follow cost-minimisation approaches. Figure number 2 shows the deteriorated environment. Basic information about these settlements shown in (table number 3 ).

The program involved 14 squatter settlements and 13 refugee camps, inhabited by more than 290000 people. The target groups mostly, are poor and unemployed, their income considered to be below the absolute poverty threshold. The implementation of the program has started in the beginning of 1999 and will be accomplished by the end of 2001.

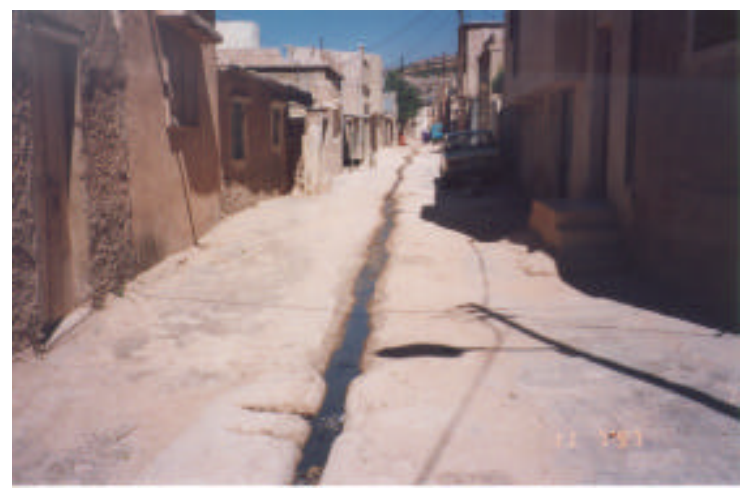

Figure 2 Wastewater floating down the clay roads in Jerash Camp

10 CIP-B is a parallel program focusing on rural areas and poor municipalities and will be managed by another government agency

\section{Site Planning and Design Concept}

The criteria which had been adopted in CIP-A projects can summarised as follows:

- Site planning should follow the existing alignment of roads and footpath where possible, in order to minimise partial or full demolishing of houses.

- All residential plots will have direct access to a surfaced footpath or road. Paved roads to be within $(100 \mathrm{~m})$ distance of any plot if possible.

- Residential plots are preferable not to exceed (10) in number on any footpath; footpath network must provide suitable access to all residential plots.

- Minimum acceptable road width not less than $6 \mathrm{~m}$

- Minimum width of footpaths $(1.5 \mathrm{~m})$.

- The project must connect to the existing circulation system through a main distributor road or a main access road depending on the existing hierarchical road system in the area.

- A hierarchical road system with road reservation width that suits site conditions is included to accommodate the vehicular and main pedestrian movements.

- Availability of parking areas to serve the majority of lots, if the site condition permits this.

- Open space to be not less than $(4 \mathrm{~m} 2)$ per plot if possible.

\section{Land Tenure}

Almost, half of the proposed upgrading projects are squatter settlements, either on government land or on private ownership land, the remaining are co-owned (Masha') ${ }^{11}$ land. Although, the program will not include the issue of solving land tenure as one of it's objectives at this stage. Therefor, the upgrading process involve plot parcelling which will be approved by the municipality, this will enable the occupants and landlords to reach appropriate settlements regarding land tenure.

However, land for public usage will be acquired from the original owners for these purposes in co-operation with concerned municipalities and Department of Land and Survey.

As, far as the land tenure issue in the camps is concerned, the government has no intention to deal with this issue, since the camps are still being considered as a temporary shelter for refugees until their political question is addressed.

\section{Relocation}

Demolition within upgrading projectwill be limited and will only take place wherever necessary to provide

11 (Masha') co-owned land, people managed to acquire a shared ownership, one legal title for large plot, each household has a certain share with no specific boundaries, they rather, altogether own the plot. 
adequate circulation and access to these areas and ensure safety measures, maximum demolition not to exceed $10 \%$.

Relocation program was designed carefully, satisfactory compensation and access to serviced residential plots in the existing site \& services projects will offered to relocates prior to the implementation of upgrading. HUDC is concerned that the living conditions of relocates should not be worsening as a result of demolition and relocation.

The amount of compensation will depend on the size, specification and age of construction of building according to well-studied and adopted criteria. Demolition and relocation process will be undertaken in full co-ordination with concerned municipalities.

\section{Cost Allocation \& Recovery Mechanism}

The existing cost recovery practices for similar quality of services according to the standards practice in Jordan are as follows:

Roads and footpaths. Beneficiaries are charged $50 \%$ of the capital cost of new roads and footpaths (local authorities cover the balance), and $100 \%$ for new sidewalks.

Water supply: beneficiaries are only charged for house connections, while the network cost born by Water Authority of Jordan (WAJ)

Sewer: the cost of network, treatment plan maintenance and operation are born by WAJ. The beneficiaries are charged the house connection and $25 \%$ of the rental value paid one tome only.

Drainage: Local Authorities pay $100 \%$ no charges to beneficiaries.

Street lighting: Local Authorities pay $100 \%$ no charges to beneficiaries.

Social facilities: (schools, clinics and community centres); the cost of construction, maintenance and operation are born by the concerned government agencies.

Although CIP-A is designed to provide grant finance for some of the capital costs of infrastructure targeted to poor communities, direct recovery cost from beneficiaries under CIP -A will largely follow the existing practice, households will pay all normal connection and usage cost such as water and electricity tariffs. However, it still may not be possible to achieve the anticipated cost recovery.

\section{Community Development and Gender Issues}

As previously mentioned in the background, CIP-A is the fourth component of the national social productivity program (SPP) which is targeted to poor areas to enhance their productivity through the implementation of a set of sub-programs to enable them to have better access to training and micro-finance opportunities. Female-headed households will be given special attention in this regard.

As part of CIP-A, community facilities include; schools, clinics and community centres will provided to ensure social and health development. Community centre's activities will be targeted to disadvantaged groups, women in particular to train them and promote their involvement in development process.

\section{Actors and Roles}

The Community Infrastructure Program CIP-A is a national program, involve different actors, but HUDC has the leading role in this program because of its long experience in upgading

\section{HUDC}

The responsibilities of HUDC as the major actor are as follows:

- Program design in co-operation with Ministry of Planning

- Overall program management

- Project design

- Criteria design for infrastructure services and community facilities in co-ordination with relevant government agencies

- Program implementation through local contractors

- Financial management

- Awareness campaign

- Undertake socio-economic and environmental surveys

- $\quad$ Project follow-up and monitoring

Ministry of Planning

This ministry is Sponsoring CIP which is the fourth component of the national program SPP, it has the following responsibilities

- Participate in program design

- Program follow -up and monitoring

- Mobilise and monitor financial resources

\section{Services Governmental Agencies}

Include all ministries and institutions concerned with infrastructure and community facilities. They were involved in design criteria and responsible for operation and maintenance of these services. The Department of Land and Survey is a supporting governmental agency, which was responsible for providing the necessary maps.

\section{Department of Palestinian Affairs (DPA)}

The DPA is the government agency responsible for refugee camps affairs all over the country. It has the following tasks in this program:

- Participate in criteria design for refugee camps

- Approving the detail design for each camp

- Participate in community awareness campaign

- Participate in the follow-up and implementation process

\section{Municipalities}

Municipalities have essential and supporting role during the different stages of CIP-A course; these tasks are as follows:

- Review and approve layout of each of the squatter settlement project

- $\quad$ Acquire the land designated for public use like; circulation networks and community facilities

- Follow -up demolition and relocation process 
- Reviewing and approving compensation criteria

Financing Agencies (international, regional and local)

- Provide necessary fund (in form of grants or soft loans) to implement the infrastructure services and community facilities

\section{Target Group}

HUDC had launched a comprehensive awareness campaign in squatter settlements during mid 1998 include; public meetings with community leaders and key persons and house visit, to explain the program objectives, identify target group needs and priorities and promote their involvement in the upgrading process. Community leaders are anticipated to play an important role in the relocation process and ensure ease and smooth implementation of demolition and relocation actions.

In the meantime, HUDC undertake the same campaign in the refugee camps in co-ordination with DPA, Camp Improvement Committees which are elected by the camp residents could express their perspectives clearly and identify the needs and priorities of infrastructure services.

Furthermore, HUDC is currently involved in conducting a socio-economic and environmental baseline surveys, in all squatter settlements and camps to assess the attitudes of the target group towards the program, and collect the necessary data to help planners and decision makers to decide the component of each project and to be used as a database for future impact assessment.

\section{Conclusions and Recommendations}

\subsection{Strategies}

\section{Parallel Low -Cost Housing}

Provision of low-income housing (site \& services) schemes parallel to the upgrading during the implementation of the first and second approach, proved to be essential, it provided the opportunity for overcrowded households and demolition cases in upgrading to have access to adequate ${ }^{12}$ low-cost housing schemes. Although, the target group in the anti-poverty approach still has access to the existing site \& services, but the majority of the poor people can't afford to buy in these housing schemes, due to the high cost.

\section{Land Issue}

In both, the first and the second approach, residents managed to secure the land title for their plots. Though,

\footnotetext{
12 Adequate low-cost housing - a core unit of minimum $30 \mathrm{~m}^{2}$ constructed on $150 \mathrm{~m}^{2}$ serviced plot connected to all infrastructure services in site \& services project
}

the land cost in the first approach, in particular Amman upgrading projects, was relatively high, since the land was owned by private owners. Government could not mange to acquire it at a low price. While, upgrading projects in the second approach were developed on government land. Therefore, squatters including 'Tawsieya' holders, where a real pressure was put forward by local authorities and other concerned decision makers, were succeed to secure the land title at very low price.

However, in both approaches, beneficiaries felt safer and had interacted positively with the infrastructure services. The joint assessment study, which had been conducted by HUDC and the Urbanisation Unit in Harvard University during 1992 and 1993, showed a significant upgrading sustainability. Land issues, beside other issues, had led to this sustainability.

The anticipated anti-poverty program, will not handle the land issue directly in squatter settlements, because this issue is associated with many complicated problems and involved different types of land ownership. In the meantime the program is targeted to poor groups to enhance their living environment, not to increase their financial burdens. Therefore, the program will provide final and approved plans with individual plot boundaries, which considered essential step towards solving the land tenure at later stages.

\section{Relocation}

In general, the government strategy in the upgrading projects to minimise the demolition as much as possible, to avoid social disruption. HUDC demolition experience in the first approach, in particular in Amman upgrading projects, was so conservative. However, demolition cases had been compensated for their houses and given access to services plots in the site $\&$ services schemes. Some households were not being able to construct new houses on the new plots before they had evacuated the old ones.

The relocation process in Aqaba upgrading projects was significantly enhanced. Social and economic conditions of individual household were studied and assessed carefully, different types of core units were constructed on the in-fill plots in the same projects prior to the implementation. In the second approach, which had involved partnership with local authorities, relocation process was studied and planned by all partners. Demolition cases received satisfactory compensation for their houses and given access either to a subsidised serviced plot or core unit in adjacent site \& services scheme. Moreover, HUDC provided the necessary support for affected households to move and settle in the new houses. Follow -up studies conducted later by HUDC indicated the high level of satisfactory among relocates.

In the third approach, the government somehow, tends to maintain the same strategy. Demolition will be limited as possible, it will only take place wherever necessary to provide adequate circulation and access to ensure safety measures. Relocation will be implemented in full co- 
operation with municipalities; compensation criteria were discussed thoroughly with all concerned actors to ensure equity and fairness. Although, no core units will be available, but affected households still have access to a limited types of serviced plots in the existing site \& services schemes, therefore, some households might not be able to buy such plot, with relatively high price, and construct new house on it.

\section{Cost Allocation \& Recovery Mechanism}

The strategy adopted in the first approach based on full cost recovery principal. Beneficiaries had paid the entire cost of infrastructure; the cost was higher than what the general people are paying, and some of them hardly managed to pay the cost. They had suffered of financial difficulties as a result of this approach. Therefore, the majority had paid the cost through mortgage loans from JHB.

As part of the second approach, HUDC had revised the cost allocation mechanism with concerned government agencies; they reached to more reasonable strategy, which follows the normal government practice in other similar areas. Beneficiaries had to pay less than $50 \%{ }^{13}$ of the infrastructure services cost to local authorities.

The same strategy will be applied in the third approach, although beneficiaries will not be asked to pay the cost of these services at this stage, the concerned agencies rather will collect the cost on the long run through their normal cost recovery practice.

\subsection{Actors}

The implementation of the upgrading process involved many actors. Although, HUDC considered the major actor in the first approach, where the upgrading had been experienced for the first time, to ensure appropriate provision of all infrastructure services and community facilities, the role of local authorities was very limited.

The target group was not involved in all stages of upgrading, their needs was considered through the socioeconomic survey prior to implementation, but they were involved entirely in the process of improving their own dwellings, house design was done in full co-operation between them and HUDC architectures. Moreover, the household members participated in the construction activities which done by a local contractor under supervision of HUDC technical staff.

In the second approach, local authorities and target group had more effective role during the different stages of the upgrading process; both were involved in deciding cost allocation, relocation and site planning. This experience proved to be more efficient, but at the same time had

\footnotetext{
13 the balance is born by other concerned agencies and local authorities
}

created some conflicts and delay the completion dates, nevertheless the advantages outweigh the disadvantages.

The anti-poverty approach is a national-wide program, which involve the upgrading of 14 squatter settlements and 13 refugee camps all over the country. In this approach, HUDC is acting as the major actor in full coordination with the local authorities and other concerned government agencies. Due to the limited time of the program course, the target group had not the chance to participate directly in the planning stage, therefore HUDC had launched comprehensive awareness campaign to educate them on program objectives and assess their attitudes towards it's components. However the target group, as part of the program, will be trained and encouraged to maintain the infrastructure services functioning properly.

\subsection{Design}

The basic design concept in all three approaches had not been changed. The major concern for HUDC to meet the minimum service quality standards and follow costminimisation approaches. The construction of the entire infrastructure services was done at the same time to ensure adequate and sustainability of these services.

The upgrading projects must connect to the existing circulation system through main access road depending on the existing hierarchical road system in the area. In the first approach, roads and footpaths in Amman upgrading projects were kept to their existing width to avoid demolition, since it is the first upgrading experience in Jordan, while in the following approaches, new roads and footpaths were introduced to provide efficient circulation network and ensure safety measures.

Parking and green areas were provided as possible in all projects to serve the majority of the residential plots. Furthermore, commercial plots and workshops were provided and sold at market price to provide gross subsidy to the residential plots. The community facilities had been designed to serve the beneficiaries and the neighbourhood areas as well. 
Table 3 Basic information on squatter settlements and refugee camps included in CIP-A

\begin{tabular}{|c|c|c|c|}
\hline Project & Area h & Households ${ }^{14}$ & location \\
\hline \multicolumn{4}{|c|}{ Squatter settlements } \\
\hline Wadi Abdoun & 3.8 & 208 & Amman \\
\hline Al Hashimi & 2.2 & 282 & Amman \\
\hline Misdar & 0.7 & 56 & Amman \\
\hline Wadi Haddada & 1.9 & 189 & Amman \\
\hline Lawzieya & 2.2 & 340 & Amman \\
\hline Zawahra & 4.7 & 102 & Amman \\
\hline Qiesya & 14.7 & 584 & Amman \\
\hline Natheif & 8.7 & 1191 & Amman \\
\hline Nuzha & 1.8 & 377 & Amman \\
\hline Wadi Qattar & 18.0 & 130 & Amman \\
\hline Musherfa & 20.5 & 1306 & Amman \\
\hline Abu Sayah & 12.5 & 86 & Amman \\
\hline Jena'a & 24.0 & 1673 & Zarqa \\
\hline Hai Tafayla & 3.9 & 914 & Amman \\
\hline \multicolumn{4}{|l|}{ Refugee camps } \\
\hline Madaba camp & 11.2 & 750 & Madaba \\
\hline Zarqa camp & 18.9 & 1124 & Zarqa \\
\hline Souf camp & 59.6 & 1453 & Jerash \\
\hline Talbeiya camp & 13.3 & 615 & Amman \\
\hline Jerash camp & 50.7 & 1977 & Jerash \\
\hline $\begin{array}{l}\text { AL Hussein } \\
\text { camp }\end{array}$ & 33.8 & 3871 & Amman \\
\hline Baqa camp & 130.7 & 8080 & Balqa \\
\hline Sukhna & 6.9 & 565 & Zarqa \\
\hline Wahdat camp & 47.7 & 4523 & Amman \\
\hline Irbid camp & 21.9 & 2170 & Irbid \\
\hline Husn camp & 75.4 & 3400 & Irbid \\
\hline Marka camp & 89.4 & 5067 & Amman \\
\hline Hnykeen camp & 9.6 & 1161 & Amman \\
\hline
\end{tabular}

Source: Main Report: Community Infrastructure Program; CIP Amman 1997

\section{References}

Baseline Health and Population Assessment for Upgrading Areas of Amman, Urban Department Development, Amman 1982

Health and Population in Squatters Areas of Amman: Reassessment After Four Years of Upgrading, Urban Development Department, Amman 1986

Social Productivity Program- Community Infrastructure Program Component: Upgrading Sites and Refugee Camps, (CIP-A) Appraisal Report HUDC, Amman 1997

Project Appraisal Document: Community Infrastructure Program - Jordan, World Bank 1996

14 Jordan national census 1994, Department of Statistics, Amman 1994

\section{HUDC Quarterly Reports}

Follow-up and Monitoring Survey: Aqaba Projects, Udp3, HUDC 1996

Upgrading Shalallah and Old Town in Aqaba, Final Report: Aqaba, Dar AL Handasa 1986

HUDC Experience in Upgrading Projects: Supporting Document CIP, HUDC 1997

Hashimite Kingdom of Jordan: Poverty Assessment:

Volume 1 Main Report, World Bank 1994

Results of General Census of Population and Housing of Jordan 1994, Department of Statistics, Amman 1994

Assessing Sustainability in Aqaba Projects: A working Document Prepared by Unit of Housing \& Urbanisation: Harvard University and Housing and Urban Development Corporation 1993 